\title{
Joanna Bednarek Jak możliwa jest absolutna demokracja?
}

W ostatniej części trylogii Imperium, Rzeczy-pospolitej, Negri i Hardt pytają o sposób, w jaki wielość może rządzić sama sobą. W odpowiedzi stawiają tezę, że absolutna demokracja, pojmowana jako polityczna artykulacja wielości, niezakładająca jej redukcji do zunifikowanego podmiotu (ludu), jest możliwa. Jak stwierdza Negri, ten sposób myślenia o politycznej artykulacji jest zakorzeniony w tradycji demokratycznego materializmu, stanowiącej alternatywę dla dominującego w nowożytnej filozofii polityki nurtu utożsamiającego władzę polityczną z suwerennością. Wielość organizuje się politycznie dzięki władzy konstytuującej, tożsamej z ontologiczną kreatywnością/produktywnością wielości. Postawienie kwestii politycznej organizacji wymaga więc także postawienia kwestii składu klasowego wielości; demokracja polityczna jest zarazem demokracją ekonomiczną.

Słowa kluczowe: Negri - Hardt - Rzecz-pospolita - absolutna demokracja, władza konstytuująca - współzależne rządzenie 
Rzecz-pospolita stanowi domknięcie trylogii, na którą składają się także Imperium i Multitude. Każda z części poświęcona jest odrębnemu aspektowi ekonomicznej i politycznej konstytucji nowoczesności. Nie sposób zatem traktować poszczególnych tomów jako odrębnych całości. Podczas gdy Imperium skupia się na systemie specyficznie nowoczesnej suwerenności, kompatybilnej z postfordowskim/postindustrialnym kapitalizmem, i usuwa na drugi plan inne aspekty wspomnianej zmiany paradygmatu, tematem Multitude jest wielość jako podmiot ekonomiczny i społeczny, a potencjalnie też polityczny - podmiot produkcji, współczesny odpowiednik proletariatu. W centrum zainteresowania ostatniej części trylogii stoi natomiast kwestia politycznej konstytucji wielości, definiowanej nieraz wręcz jako „współzależne rządzenie" [governance]. Postawione zostaje więc pytanie: jak wielość może rządzić sama sobą ${ }^{1}$ ? Podkreślmy zarazem, że przez „współzależne rządzenie” nie rozumie się w tej książce formy państwa ani, ogólniej, formy transcendentnej władzy suwerennej. Wielość ma być zdolna do politycznej konstytucji nie jako zunifikowany lud, ale jako różnorodna „masa”, złożona z pojedynczości: na tym polega, w myśl Negriego, absolutna demokracja.

W Rzeczy-pospolitej Negri i Hardt stawiają więc w centrum właśnie te kwestie, które zdaniem krytyków stanowiły o pewnej słabości części pierwszej, Imperium. Przenoszą bowiem akcent z jedności podmiotu, jakim jest wielość, z jego ugruntowania w żywej pracy/produkcji biopolitycznej, na artykulację wielości jako zróżnicowanej i skonfliktowanej. Główny problem Rzeczy-pospolitej można sformułować następująco: jak uczynić z wielości podmiot polityczny? Jak stwierdzają Hardt i Negri, liczne głosy krytyczne ${ }^{2}$ - pochodzące między innymi od Slavoja Žižka i Alaina Badiou pomogły im przenieść akcent $\mathrm{z}$ kwestii bycia wielością na kwestię „tworzenia wielości” - polityczną artykulację:

[P]owinniśmy pokazać, w jaki sposób wielość jest projektem politycznej organizacji, a nie spontanicznym podmiotem politycznym. W związku z tym musimy skierować dyskusję z bycia wielością na tworzenie wielości³ ${ }^{3}$.
Nie znajdziemy tu jednak „konkretnych rozwiązań” politycznych czy instytucjonalnych, których tak domagają się zwłaszcza ci, którzy a priori uznają, że niemożliwe jest wymyślenie jakiejkolwiek alternatywy dla kapitalizmu. Spotkamy się natomiast z tym, czego brakowało w dwóch poprzednich częściach trylogii: z próbą zarysowania politycznej artykulacji wielości.

Podobnie jak „lud”, wielość jest efektem procesu politycznej konstytucji. Jednak podczas gdy lud ukształtowany jest w swej jedności poprzez hegemoniczną władzę, stojącą ponad mnogim polem społecznym, wielość formowana jest dzięki artykulacji na planie immanencji pozbawionym hegemonii $[\ldots]^{4}$.

Jesteśmy w stanie wyobrazić sobie i urzeczywistnić demokrację wielości tylko dlatego, że wszyscy podzielamy i uczestniczymy w tym, co wspólne [the common]. Przez „dobro wspólne” rozumiemy, po pierwsze, wspólne bogactwo [common wealth] materialnego świata - powietrze, wodę, owoce ziemi i wszelkie dary natury [...]. Za dobro wspólne uważamy także, co ważniejsze, te rezultaty społecznej produkcji, które są niezbędne dla społecznych interakcji oraz dalszej produkcji, takie jak wiedza, języki, kody, informacja, afekty itd. ${ }^{5}$

Commonwealth można by tłumaczyć jako „dobro wspólne” lub „wspólnotę”; oba te znaczenia są dla Negriego i Hardta równie istotne i trudno je od siebie oddzielić: chodzi zarówno o materialny, związany z produkcją charakter tego, co wspólne (zasoby naturalne i interakcje społeczne), jak i o bezpośrednio polityczny, instytucjonalny wymiar tak pojmowanego dobra wspólnego. Prawdopodobnie z tego właśnie wynika decyzja tłumaczy i tłumaczek polskiego wydania książki, którzy postanowili rozdzielić przy pomocy dywizu tradycyjny polski termin: Rzecz-pospolita. Choć trzeba przyznać, że jest to kontrowersyjny wybór translatorski, to oba powyższe znaczenia zostają $\mathrm{w}$ nim zachowane.

Polityczne, prawne i instytucjonalne przekształcenia muszą być więc przede wszystkim nakierowane na uznanie wspólnego charakteru zasobów naturalnych i informacji, gwarantować powszechny i otwarty dostęp do nich oraz zwracać się przeciwko kapitalistycznej ten- 
dencji do ich prywatyzacji ${ }^{6}$. To, co wspólne [the common], jest zarówno ekonomiczną „bazą” wspólnoty [commonwealth], jak i gwarantem jej powszechności i otwartości.

Jak jednak przełożyć ten postulat na terminy filozofii polityki? Jak rozwinąć go w spójną teorię opisującą konstruowanie się podmiotu politycznego, artykulację wspólnego stanowiska i przebieg procesów decyzyjnych? Stawką jest przedstawienie alternatywy dla, z jednej strony, liberalno-demokratycznej logiki reprezentacji, z drugiej zaś - dla postulowania powrotu do organizacyjnej dyscypliny jako jedynego sposobu na zbudowanie spójności ruchu antykapitalistycznego. Ta pierwsza perspektywa była do niedawna uznawana przez wszystkich z wyjątkiem „radykalnie lewicowych” teoretyków za jedyną możliwą do pomyślenia postać demokracji. Druga jest z kolei, mimo swojej pozornej historycznej kompromitacji, postrzegana jako konieczny warunek, który musi spełnić ruch chcący być czymś więcej niż wewnętrzną transgresją systemu kapitalistycznego, podtrzymującą ostatecznie status quo. Głównym propagatorem tego drugiego stanowiska jest Badiou$^{7}$; sekunduje mu - jak zawsze nie do końca serio Žižek ${ }^{8}$.

Trylogia Hardta i Negriego dostarcza argumentów na poparcie twierdzenia, że nie jesteśmy skazani na powyższą alternatywę. Co więcej, ukazuje też wspólne korzenie tych, wydawałoby się, krańcowo przeciwstawnych stanowisk. Zarówno logika stojąca u podstaw demokracji przedstawicielskiej, jak i logika prowadząca do tworzenia zorganizowanych pionowo, hierarchicznych organizacji, mają bowiem charakter transcendentny: chaotyczna, wieloraka całość zostaje ukonstytuowana jako jedność, spójny podmiot, za sprawą działania transcendentnej zasady: symbolicznej woli powszechnej, realizowanej za sprawą mechanizmu głosowania czy awangardy klasy robotniczej zajmującej „miejsce prawdy”. Mechanizmem pozwalającym przeprowadzić tę operację jest w obu wypadkach reprezentacja: różnorodność stanowisk składających się na całość może przetrwać operację konstytucji podmiotu politycznego tylko jako to, co reprezentowane przez uprzywilejowaną część.
Hardt i Negri pytają o możliwość innego niż reprezentacja sposobu konstytucji podmiotu politycznego: koncentrują się na zagadnieniach politycznej konstytucji wielości i struktury instytucjonalnej, jaką miałaby ona przybrać. Oznacza to powrót do tematów i perspektywy nowożytnej filozofii polityki; do, jak sami

Twierdzenie Chantal Mouffe o heterogeniczności i pęknięciu nowożytnej demokracji liberalnej nie ma w optyce Negriego i Hardta zbyt wielkiej doniosłości. Nurty liberalny i republikański razem tworzą bowiem teorię tego, co autorzy Imperium nazywają właśnie „republiką własności”

stwierdzają, „klasycznych traktatów o rządzie”. Celem autorów Rzeczy-pospolitej jest więc nie tyle przedstawienie konkretnych rozwiązań, które należałoby wdrożyć, ale pokazanie, jak (w perspektywie transcendentalnej) możliwa jest polityczna samoorganizacja wielości i na gruncie jakiej tradycji filozoficznej można ją konceptualizować. Tradycja ta zostaje ukazana na tle głównego nurtu filozofii polityki, który Hardt i Negri rekonstruują pod nazwą „republiki własności”, dążąc do uwypuklenia jego uwikłania w rozwój kapitalizmu.

Klasyczne przeciwstawienie tradycji republikańskiej i liberalnej nie ma dla Negriego i Hardta charakteru absolutnego; różnice między nimi polegają raczej na odmiennym rozłożeniu akcentów niż realnym antagonizmie czy niewspółmierności. Dlatego twierdzenie Chantal Mouffe o heterogeniczności i pęknięciu nowożytnej demokracji liberalnej ${ }^{10}$ nie ma w optyce Negriego i Hardta zbyt wielkiej doniosłości. Nurty liberalny i republikański razem tworzą bowiem teorię tego, co autorzy Imperium nazywają właśnie „republiką własności" ${ }^{11}$. Ich elementem wspólnym jest kategoria naturalnych uprawnień przysługujących każdej jednostce. Uprawnienia te stają się następnie podstawą praw politycznych. Prawo do własności nie jest przy tym tylko jednym z nich. Własność to kategoria organizująca caty system, wyznaczająca jego możliwości i granice. Reinterpretacja wszystkich naturalnych uprawnień jako 
aspektów prawa do własności to oczywiście zasługa klasycznego liberalizmu: John Locke, uznając, że człowiek jest posiadaczem własnego ciała tak samo, jak posiadaczem wytworów własnej pracy, umożliwia oparcie całego gmachu politycznych wolności na kategorii własności ${ }^{12}$. Wolność zaczyna funkcjonować przede wszystkim jako wolność do podejmowania aktywności gospodarczej; uprzywilejowaną sferą jej realizacji staje się rynek. Różnica między sprzedażą dóbr i sprzedażą siły roboczej zostaje ujęta w ramach jednej kategorii i tym samym zatarta; realność wyzysku zostaje zmistyfikowana, zepchnięta do sfery prywatnej, domeny zróżnicowań nieistotnych dla politycznej suwerenności. Sfera publiczna zostaje ufundowana za sprawą oddzielenia się od sfery prywatnej - konstytutywnego zewnętrza. To, co publiczne, jedność ludu oraz neutralność praw i instytucji, przeciwstawia się temu, co prywatne, obejmującemu zarówno zwykłą różnorodność indywidualnych wyborów stylu życia, jak i utrwalone społecznie nierówności. Tym samym republika własności, niezależnie od tego, czy chodzi o jej wersję republikańską czy liberalną, konsoliduje, pod pozorem zachowywania wolności, ekonomiczną i polityczną władzę burżuazji.

Główny nurt myśli politycznej konstruuje i wdraża ogólny schemat republiki własności; obok niego funkcjonują jednak inne, nierozpoznane jako takie, traktowane jak anomalie lub porażki.

Wbrew Žižkowi, który stawia tezę, że absolutna demokracja, gdyby była możliwa, mogłaby jedynie być równoznaczna z terrorem ${ }^{13}$, Negri i Hardt pokazują, że za pojęciem tym stoi tradycja myślenia o polityce stanowiąca alternatywę dla „republiki własności”: materialistyczne ujęcie polityczności jako mocy, potentiae.

Aby ukazać pełnię implikacji perspektywy materialistycznej dla polityki, trzeba jednak przedstawić genealogię nowożytnego demokratycznego materializmu. Jego źródła tkwią oczywiście w starożytnym atomistycznym materializmie Demokryta, Epikura i Lukrecjusza. Oprócz jednowymiarowości ontologii, czyniącej ruch atomów w próżni źródłem i tworzywem wszystkich bytów, oferuje on pierwszą teorię radykalnej innowacji: clinamen, całkowicie przypadkowe odchylenie atomów od normalnego toru ich ruchu, decydujące o możliwo- ści wolności i tego, co nowe. To powiązanie wolności i przygodności w perspektywie immanentnej ontologii Louis Althusser określił jako „aleatoryczny materializm" ${ }^{14}$; wyznaczy ono drogę myślenia o czasie i zmianie w paradygmacie materialistycznym, uznawanym tradycyjnie za niezdolny do ujęcia czasu i wypracowania dostatecznie złożonej i subtelnej jego koncepcji ${ }^{15}$.

Inicjatorem materialistycznego podejścia do polityki jest (w ujęciu Negriego) Niccolò Machiavelli, który jako pierwszy zdecydował się analizować władzę bez wiązania jej z kwestią prawomocności i sprawiedliwości ${ }^{16}$. To, co polityczne, stanowi immanentną grę sił; problem idealnego ustroju - w którym władza jest wypadkową kosmicznej lub boskiej racjonalności - w tej perspektywie zwyczajnie nie może się pojawić. Ujęcie to jest neutralne wobec zagadnienia formy rządów - królestwa, księstwa i republiki różnią się od siebie sposobem konfiguracji politycznych podmiotów-sił (na przykład rolą, jaką odgrywa lud), ale nie istotą. W każdym zaś z ustrojów lud jest jedną z najistotniejszych sił, z którymi należy się liczyć; zapewnienie sobie jego akceptacji jest najpewniejszym sposobem utrzymania władzy w monarchii lub księstwie, w republice zaś stanowi on ambiwalentną siłę, dającą podstawy konstytucji państwa, będącą przyczyną jego stabilności, ale też zepsucia i upadku ${ }^{17}$.

Teksty Machiavellego można oczywiście czytać jako swego rodzaju podręczniki dla władców, opisujące niezależne od ustroju państwa prawidłowości rządzące praktyką sprawowania władzy i biorące pod uwagę tylko jedną stawkę - utrzymanie władzy w państwie. Być może są one faktycznie przykładami ,realizmu politycznego"; Negri podkreśla jednak, że takie ich zaklasyfikowanie sprawia, iż umyka nam innowacja, jaką stanowi ich perspektywa: prawa zredukowane do wypadkowej politycznych sił, władcy i ludy na równi traktowani jako podmioty.

Machiavelli wprowadził również do teorii polityki atomistyczne pojęcie clinamen - odchylenia w postaci „przemiany” [mutatio]. Polityka staje się dzięki temu przestrzenią, w której pojawia się to, co nowe. Mutatio to innowacja, zmiana układu sił, tyleż obiektywna, co podmiotowa; Machiavelli stawia sobie za zadanie opisać warunki jej możliwości ${ }^{18}$. Możliwość politycznego wydarzenia nie zależy tu, jak u Badiou, od wystąpienia ano- 
malii obcej porządkowi ontologicznemu, ale jest wpisana w ten porządek.

Powiązanie materialistycznego podejścia do polityki z teorią demokracji jest zasługą Spinozy; stało się ono możliwe za sprawą skonstruowanej przez niego ontologii, łączącej jednoznaczność bytu z apoteozą ludzkiej aktywności. Swymi dwiema pracami dotyczącymi Spinozy Negri wpisuje się w nurt interpretacji tego filozofa jako myśliciela radykalnej immanencji i demokracji (inni jego przedstawiciele to Pierre Macherey, Gilles Deleuze i Étienne Balibar) ${ }^{19}$. Podobnie jak Deleuze, kładzie on nacisk na kategorię jednoznaczności bytu, eliminującą ontologiczne hierarchie wprowadzane przez byt analogiczny ${ }^{20}$. Substancja, wyrażając się w modusach (Negri idzie śladami Deleuze'a, kładąc nacisk na pojęcia ekspresji ${ }^{21}$ ), wyczerpuje się w nich całkowicie; byt jest immanentny. Spinoza stworzył teorię artykulacji bytu stanowiącą alternatywę dla artykulacji dialektycznej, nieuciekającą się do kategorii zapośredniczenia i transcendentnej instancji regulującej jej przebieg (tym bowiem jest dla Negriego Heglowski duch); ten sposób artykulacji autor Imperium nazywa konstytucja ${ }^{22}$. Konstytucja, widoczna w działaniu w Etyce, jest sposobem wyrażania się bytu jako produktywnej, nieskończonej całości, której przyczyną immanentną jest substancja. Jak podkreśla Negri, mimo iż część pierwsza Etyki rozpoczyna się definicjami substancji, atrybutu i modusu, nie mamy tu do czynienia z absolutnym początkiem. Substancja nie jest arche, nadającą prawo bytowi, nie jest też jego źródłem; Etyka zaczyna się in medias res ${ }^{23}$ i traktuje o kolistości bytu, pełni pozbawionej transcendencji, totalności godzącej się z otwartością ${ }^{24}$. Ani substancji, ani modusom nie przysługuje ontologiczny prymat.

Tutaj staje się jednak oczywiste, że jeśli pozostajemy w obrębie samej ontologii, nie sposób utrzymać tezy o kolistości bytu: substancji, jako przyczynie immanentnej, musi przysługiwać prymat wobec modusów. Ta wizja ontologii Spinozy pozostaje jednostronna. Negri wyróżnia, analizując rozwój myśli Spinozy, dwie jej podstawy: pierwsza z nich, zstępująca, opisana powyżej, wychodzi od pojęcia substancji jako przyczyny immanentnej i, przyznając jej status nadrzędny, zbliża się do neoplatońskiego modelu bytu jako emanacji. Jej jednostronność stała się przyczyną wewnętrznego kryzysu ewolucji filozoficznej autora Etyki. W latach 1665 1670 Spinoza przerywa pracę nad Etyka, by pisać Traktat teologiczno-polityczny ${ }^{25}$; jednak ścisłe powiązanie problematyki ontologicznej i etyczno-politycznej da się

Konstytucja jest sposobem wyrażania się bytu jako produktywnej, nieskończonej całości, której przyczyną immanentną jest substancja

dostrzec już we wczesnym Traktacie o poprawie rozumu ${ }^{26}$, świadcząc o dostrzeganej przez niego od początku niewystarczalności perspektywy konstytucji „odgórnej”. Druga (wstępująca) podstawa zakłada zatem prymat modusów i przyznaje ludzkiej twórczej praktyce etycznej i politycznej status czynnika odpowiadającego za oddolną konstytucję bytu. Zauważmy, że interpretacja Deleuze'a nie zakłada istnienia tych dwóch podstaw i pozostaje przy tezie o prymacie substancji w filozofii Spinozy; powstaje tym samym konieczność uzupełnienia tej filozofii innymi teoriami, by skonstruować prawdziwie immanentną ontologię ${ }^{27}$.

Jednostkowy modus jest ciałem, czy ściślej - złożeniem ciał. Każde ciało jest zaś wyposażone w siłę, każącą mu dążyć do wytrwania w istnieniu, w postaci zgodnej z jego naturą. Dążność [conatus] nie jest właściwie niczym innym, niż jednostkową naturą każdej rzeczy ${ }^{28}$ :

Każda rzecz tak dalece, jak jest sama w sobie, dąży do zachowania swego bytu. [...] dążność [conatus] każdej rzeczy do zachowania swego bytu nie jest niczym innym, jak treścią czynną tejże rzeczy [...]. Dowód. [...] moc, czyli dążność, z jaką każda rzecz działa lub dąży do działania bądź osobno, bądź razem z innymi rzeczami, tj. moc, czyli dążność do zachowania swego bytu, nie jest niczym innym, jak daną, czyli czynną treścią tejże rzeczy ${ }^{29}$.

Conatus nie ma, w interpretacji Deleuze'a i Negriego, nic wspólnego z samozachowaniem; stanowi raczej dążenie ciała do największego możliwego rozwoju siły, w którą jest wyposażone. Rozwój ten, zwiększenie własnej siły, zapewniają spotkania wzmacniające dane ciało 
i zwiększające jego aktywność. Łączenie sił, wiążące się z powstaniem wspólnoty, zwiększa siły poszczególnych jednostek; jest to jedyne uprawomocnienie wspólnoty politycznej. Pozostajemy tu w dalszym ciągu na planie mocy [potentia]; ciało polityczne, podobnie jak ciała fizyczne, stanowi złożenie jednostkowych sił i ciał, nie zaś jedność, wynikającą z przekształcenia masy-wielości [multitudo] w lud za sprawą nadania jej politycznej formy. Trzeba podkreślić, że w konsekwencji powstanie państwa nie zakłada, w rozumieniu Spinozy, transferu uprawnień jednostkowych do władzy suwerennej. Ma ono miejsce zarówno w koncepcji monarchii absolutnej Hobbesa, jak i w koncepcji republiki Rousseau. Obaj filozofowie stwierdzają, że jedynym sposobem zachowania naturalnych uprawnień przy przejściu od stanu natury do stanu uspołecznienia jest przeniesienie naturalnego uprawnienia do nieograniczonego korzystania z jednostkowej wolności na władzę suwerenną; prawa polityczne przysługujące jednostkom w stanie uspołecznienia są konsekwencją ich statusu jako części niepodzielnego ciała politycznego ${ }^{30}$. Transfer praw ma miejsce, ponieważ przejście od stanu natury do stanu uspołecznienia, dokonujące się poprzez umowę społeczną, ma charakter radykalnej zmiany jakościowej; w Spinozjańskiej teorii uspołecznienia przeciwnie: uspołecznienie jest tylko przemianą ilościową, zwiększeniem mocy części składowych wspólnoty; nie ma zatem potrzeby tworzenia transcendentnej instancji władzy suwerennej.

Horyzont polityczno-ontologiczny Etyki utworzony jest przez przeciwstawienie dwóch rodzajów władzy: potentia i potestas (rozróżnienie to jest istotne również dla Deleuze'a i Guattariego, których myślą inspirują się autorzy trylogii Imperium) ${ }^{31}$. Pierwsza z nich to immanentna moc bytu i ludzkiej wielości; druga to władza państwowa, suwerenność.

Jak podkreślają zarazem Negri i Hardt, nowożytna suwerenność była ściśle skorelowana z kapitałem:

W polityce, tak jak w metafizyce, tematem dominującym było [...] eliminowanie średniowiecznej postaci transcendencji, która tylko hamuje produkcję i konsumpcję, a zarazem utrzymanie właściwych transcendencji efektów panowania [...]. Reprezentacja, która służy legitymizo- waniu suwerennej władzy, całkowicie ją też alienuje ze zbiorowości poddanych ${ }^{32}$.

U podstaw nowoczesnej teorii suwerenności tkwi jednak jeszcze jeden ważny element - pewna treść, która wypełnia i podtrzymuje formę władzy suwerennej. Tę treść stanowi rozwój kapitalistyczny i afirmacja rynku jako podstawy wartości tworzonych w drodze reprodukcji społecznej ${ }^{33}$.

Wielu filozofów opisywało przejście do tego, co polityczne, jako utworzenie jednolitego podmiotu - ludu, odróżnianego od wielości, która stanowiła dla nich byt przedpolityczny: masę, zbiór jednostek, niejednolitą zbieraninę ${ }^{34}$, która stanowi najwyżej surowy materiał dla formowania się ludu. To rozróżnienie między wielością i ludem miało, jak podkreślają Hardt i Negri, wyraźny charakter klasowy: wielość - niejednolita zbieranina, była utożsamiana z biednymi jako grupą istotowo niezdolną do współtworzenia woli powszechnej.

Nowożytne teorie suwerenności naznaczone są błędem absolutyzacji władzy [potestas], którą przedstawiają jako autonomiczną i jakościowo odrębną od mocy [potentia], podczas gdy w rzeczywistości jest ona tylko pochodną, jednym z efektów mocy. Prawo nie jest ontologicznie samodzielne; da się zredukować do mocy ${ }^{35}$. To samo dotyczy suwerennego, jurydycznego modelu władzy.

Prymarność władzy suwerennej jest zatem wynikiem ideologicznej mistyfikacji; dlatego Negri i Hardt konstruują dla niej materialistyczną alternatywę w postaci władzy konstytuującej. Tradycyjnie rozumie się ją jako źródło zarówno prawomocności, jak i mocy instytucji politycznych; jest ona siłą nadającą formalnej, spisanej konstytucji państwa i ustanowionym przez nią instytucjom status bezpośredniej ekspresji woli obywateli. Paradoks władzy konstytuującej polega na tym, że nieuchronnie aktualizuje się ona w porządku konstytucyjnym, normach i instytucjach, przekształcając się we władzę ukonstytuowaną; podlega tym samym alienacji, traci swój potencjał twórczych przekształceń, politycznych innowacji. W swojej pracy poświęconej genealogii idei władzy konstytuującej w nowożytnych teoriach materialistycznych ${ }^{36}$ (od Machiavellego do Lenina) Negri 
zauważa, że w filozoficznych analizach władzy, jak również w prawniczych teoriach porządku konstytucyjnego, mamy do czynienia z zadziwiającą niemożnością przedstawienia władzy konstytuującej; jej paradoksalny charakter zostaje w konsekwencji zatarty lub zaprezentowany jako nieuchronny strukturalny efekt, co poważnie ogranicza zdolność do zakwestionowania istniejących porządków konstytucyjnych (czyli głównie demokracji przedstawicielskiej) i projektowania alternatyw dla demokratycznej konstytucji.

W dyskursie prawniczym władza konstytuująca zostaje zredukowana do źródła norm konstytucyjnych, a zatem pozbawiona swojego nadmiarowego charakteru i zrekonstruowana jako efekt władzy ukonstytuowanej, wyrażającej się w instytucjach państwowych: instytucje stają się jedynym możliwym do pomyślenia źródłem władzy konstytuującej ${ }^{37}$. Na dodatek demokratyczna konstytucja jest zwykle w ich obrębie utożsamiana z reprezentacją jako jedynym możliwym do pomyślenia mechanizmem przekształcającym różnorodne pragnienia wielości w wolę obywateli/ludu. Rząd przedstawicielski nie jest formą władzy nastawioną na udział obywateli w sprawowaniu władzy czy zatarciu rozróżnienia na rządzących i rządzonych; jego zadaniem jest selekcja, przesiewanie roszczeń wielości tak, by w sferze publicznej zaistniały tylko te możliwe do pogodzenia z horyzontem republiki własności: kryteria reprezentacji sprawiają, że jest ona zawsze (w mniejszym lub większym stopniu - niemniej dotyczy to również czasów współczesnych) - reprezentacją właścicieli ${ }^{38}$.

Dyskurs filozoficzny natomiast zwykle utożsamia władzę konstytuującą z władzą suwerenną; paradoks władzy konstytuującej przybiera postać paradoksu władzy suwerennej. Władza pojmowana jest tu jako niepodzielna i funkcjonująca zgodnie z autonomiczną, swoiście polityczną logiką. Jej paradoks polega zaś na tym, że prawo, które tworzy, funkcjonuje jedynie za sprawą konstytutywnego zewnętrza - nadwyżki władzy, która musi zostać wykluczona, znaleźć się poza prawem.

By postawić pytanie o możliwość wyjścia poza paradoks władzy konstytuującej, Negri zwraca się więc ku myślicielom i działaczom zaliczanym przez niego do linii materialistycznej immanencji39. Czy da się pomyśleć władzę konstytuującą, która nie zostaje zanegowana, nie wyczerpuje się w procesie konstytucji, a zarazem nie funkcjonuje w oparciu o logikę konstytutywnego zewnętrza/włączającego wyłączenia? Stawką jest tu sama możliwość politycznej innowacji - szansa na wynalezienie nowych form demokracji, niebędących już elementem republiki własności. Dotychczasowy, demokratyczno-liberalny podział na to, co polityczne, i to, co gospodarcze, sferę prywatną i publiczną, ma bowiem charakter neutralizacji rzeczywistego produktywno-politycznego potencjału mas:

Nowoczesność jest [...] negacją jakiejkolwiek możliwości, aby wielość mogła wyrażać siebie jako podmiotowość. [...] neutralizacja wielości poprzez to, co polityczne wymaga jej izolacji w tym, co społeczne. Ta [...] operacja zakłada stworzenie osobnej nauki, czy nazwiemy ją ekonomią polityczną, czy socjologią; jej zadaniem jest oddzielenie mocy społecznej od władzy politycznej - a nawet, lepiej czy prościej, tego, co społeczne, od tego, co polityczne ${ }^{40}$.

Władza konstytuująca nie jest w gruncie rzeczy niczym innym, jak ontologiczną kreatywnością mas/wielości, ich praca, pojmowaną w szerokim znaczeniu - jako każda aktywność przyczyniająca się do wzbogacenia rzeczywistości naturalnej i społecznej, a także, śladem Deleuze'a i Guattariego, jako pozytywne i nienaznaczone brakiem pragnienie. Jest ona bezpośrednią przyczyną konstytucji wielości jako podmiotu politycznego: „Żywa praca konstytuuje świat poprzez twórcze modelowanie, ex novo, materiałów, których dotyka [...]. Pierwszym rezultatem tego nieograniczonego procesu jest konstrukcja podmiotu." ${ }^{1}$.

Podstawą immanentnej organizacji politycznej jest samorozwój [autovalorizacione] wielości. Zgodnie z teoretykami operaismo postulat samorozwoju 
zakłada zyskiwanie autonomii przez klasę robotniczą dzięki wyjściu poza kapitalistyczne relacje pracy, zyskanie niezależności od nich, co Tronti ujmuje w formule odmowy pracy ${ }^{42}$. Jest ona konieczna, żeby uwolnić się od kapitalistycznej kontroli, jaką wprowadza stosunek pracy, nieuchronnie wiążący się z wyzyskiem. Nie oznacza to rzecz jasna rezygnacji z pracy (i związanego z nią rozwijania naszego potencjału kreatywności) w ogóle, ale tylko odmowę partycypacji w jej formach nadkodowanych przez kapitalistyczne stosunki produkcji. Jak zauważa Kathi Weeks ${ }^{43}$, temat odmowy pracy, pojawiający się pod postacią exodusu, jest centralny dla projektu przedstawionego w Imperium. Ma on dwa momenty: negatywny, zakładający porzucenie, i pozytywny, czyli tworzenie nowych form współpracy i wspólnoty. Trzy postulaty, które wysuwają Negri i Hardt w zakończeniu Imperium, dają pewne pojecie o normatywnych wyznacznikach tych nowych form życia-produkcji. Postulat wprowadzenia powszechnego dochodu gwarantowanego, wolność przemieszczania

\section{Demokracja polityczna musi być więc zarazem} demokracją ekonomiczną: władza konstytuująca musi polegać na zawłaszczeniu przez masy społecznej produkcji i reprodukcji

się lub pozostawania w miejscu (zamiast wymuszonej przez rynek mobilności), prawo do ponownego przywłaszczania tego, co wspólne (zwracający uwagę na nieadekwatność formy własności prywatnej; ruch copy left) to zasady fundujące, na bardzo ogólnym poziomie, nowy porządek globalny, którego podstawą i zarazem celem jest dobro wspólne.

Demokracja polityczna musi być więc zarazem demokracją ekonomiczną: władza konstytuująca musi polegać na zawłaszczeniu przez masy społecznej produkcji i reprodukcji ${ }^{44}$. Władza konstytuująca musi także, aby nie wyczerpywać się we władzy ukonstytuowanej i stanowić obszar politycznej kreatywności, mieć charakter autonomicznej wobec swoich aktuali- zacji, całkowicie pozytywnej potencjalności; potencjalność zostaje utożsamiona z twórczą mocą [potentia] życia, otwartością horyzontu tego, co społeczne.

Ugruntowanie mocy konstytuującej w żywej pracy musi jednak zakładać postawienie pytania o skład klasowy wielości w epoce hegemonii pracy biopolitycznej. Pytanie to wcale nie jest przestarzałe (jak mogłoby się wydawać na podstawie pewnych stwierdzeń z Imperium $^{45}$ ). Aby postawić kwestię politycznej artykulacji wielości, trzeba pokusić się o rekonstrukcję jej składu klasowego. Realizacja tego postulatu w Rzeczy-pospolitej może się wprawdzie wydawać niezadowalająca, jeśli chodzi o zdanie sprawy z empirycznej złożoności składu klasowego; niemniej sam kluczowy problem zostaje sformułowany.

Jako najważniejsze elementy składu technicznego (czyli organizacji procesu pracy) w dobie hegemonii pracy biopolitycznej podają Negri i Hardt: utowarowienie życia, które staje się podstawą wytwarzania wartości dodatkowej, feminizację pracy (przez co rozumieją zacieranie się granic między produkcją i reprodukcja), oraz pojawienie się nowych wzorów migracji związanych z globalnym podziałem pracy ${ }^{46}$. Nie ma zatem mowy o stopniowym ujednolicaniu się zglobalizowanej gospodarki; podczas gdy w Imperium Hardt i Negri zdawali się sądzić, że podział na centrum i peryferie rychło stanie się nieaktualny, w Rzeczy-pospolitej $j^{47}$ dostrzegają fakt, że kapitał nieustannie odtwarza podziały wzdłuż granic sektorów geograficznych, utrwalając asymetryczne relacje miedzy nimi.

Skład organiczny (pojęcie to odnosi się do podstawy antagonizmu między pracą a kapitałem) można natomiast scharakteryzować poprzez odniesienie do jednej głównej cechy: w dobie hegemonii pracy niematerialnej głównym mechanizmem akumulacji jest wywłaszczanie tego, co wspólne. Odwołując się do rozróżnienia na skład techniczny i organiczny, Negri i Hardt wydają się podkreślać, że kapitał/Imperium nie jest, jak stwierdzali w pierwszej części trylogii, wyłącznie siłą kontroli i represji, działającą na żywą pracę z zewnątrz ${ }^{48}$. Niektóre sformułowania z Rzeczy-pospolitej mogą potwierdzać to wrażenie. Autorzy piszą na przykład: 
Kapitał nie jest oczywiście czystą formą sprawowania kontroli, lecz relacją społeczną. Jego przetrwanie i rozwój zależą natomiast od produktywnych podmiotowości, które istnieją w jego ramach, ale pozostają wobec niego antagonistyczne ${ }^{49}$.

W rzeczywistości jednak między Imperium, Multitude i Rzecza-pospolitą istnieją różnice polegające raczej na przesunięciu akcentów niż na radykalnej zmianie perspektywy. Z faktu, że kapitał jest stosunkiem społecznym, nie zostaną wyciągnięte wnioski mogące doprowadzić do przeformułowania teorii głoszącej, że praca biopolityczna organizuje się w sposób autonomiczny, niezależnie od kapitału: „kapitał [...] nie organizuje produktywnej kooperacji" "50.

Samo uznanie, że kapitalistyczna akumulacja odbywa się w coraz większym stopniu głównie za sprawą wywłaszczenia, a zatem że głównym źródłem zysku w neoliberalnej gospodarce są nie inwestycje w produkcję, a mechanizm renty, jest stosunkowo mało kontrowersyjne - stanowisko to (choć nieco inaczej formułowane) podziela z autorami Rzeczy-pospolitej wielu innych teoretyków ${ }^{51}$. Wydaje się jednak, że Negriemu i Hardtowi chodzi o coś innego: zdają się oni mówić, że nawet w przypadku inwestycji w produkcję mamy do czynienia z zewnętrznością kapitału wobec pracy. W tym kontekście stwierdzenie, że wielość produkuje dobrze i wydajnie tylko na własnych warunkach ${ }^{52}$, może sprawiać wrażenie nieco dwuznacznego - jak miałyby wyglądać te warunki, skoro organizacja pracy biopolitycznej już dziś jest niezależna i zewnętrzna wobec kapitalistycznego mechanizmu zawłaszczającego jej produktywność?

Techniczny skład wpływa na skład organiczny umiejętności wykorzystywane w pracy wpływają na umiejętność politycznego artykułowania postulatów ${ }^{53}$. Negri i Hardt w dalszym ciągu, podobnie jak w Imperium, utrzymują, że współcześnie dominujące formy produkcji zakładają konieczność uwolnienia informacji, kreatywność i współpracę, które muszą być niezależne od kapitalistycznego dyktatu ${ }^{54}$. „Polityczn[a] ścież[ka] konstrukcji wielości wraz z Imperium” ${ }^{55}$ musi przybrać postać podyktowaną jej przez te formy produkcji. Fakt, ze sama praca biopolityczna jest już w pewnym stopniu upolityczniona, umożliwia skon- struowanie modelu demokratycznego podejmowania decyzji, niezapośredniczonego przez mechanizm reprezentacji ${ }^{56}$. Dlatego sieć, wprowadzona w Multitude ${ }^{57}$, w dalszym ciągu jest dla naszych teoretyków najlepszym modelem demokratycznego podejmowania decyzji typem komunikacji, za sprawą której pojedynczości „mogą razem działać” ${ }^{8}$. Jednocześnie zaś podkreślają oni, że polityczna artykulacja wielości uzależniona jest od dynamiki kryzysów kapitalizmu i związanej z nią dynamiki ruchów antysystemowych; o tym, jaką przybierze postać, decyduje rozwój konkretnych ruchów społecznych. Sprawą kluczową dla tworzenia tych „rewolucyjnych układów” 59 jest przecinanie się [intersection] lub wzajemna translacja pomiędzy poszczególnymi walkami, umożliwiająca pomnożenie ich mocy ${ }^{60}$. Tylko komunikacja między poszczególnymi ruchami tworzy nowe formy życia, „nowy zestaw kolektywnych nawyków i praktyk" ${ }^{\prime \prime}$. Jak zauważa Negri w odniesieniu do obecnej fali walk uniwersyteckich i antykapitalistycznych: ruchy te „[s]ą polityczne, ponieważ znajdują się na obszarze konstytuującym, a nie obszarze stawiania żądań" ${ }^{2}$. W szczególności, jak poświadcza zarówno sam Negri, jak i inni komentatorzy ${ }^{63}$, ruch Oburzonych świetnie pokazuje, jak może wyglądać w praktyce działanie władzy konstytuującej i polityczna artykulacja wielości.

Demokracja bezpośrednia nie jest mitem, niemożliwą do zrealizowania utopią czy fantazmatem, którego realizacją byłby wyłącznie terror. W rzeczywistości ta forma demokracji ma swoje sposoby organizacji podmiotu i jego procesu decyzyjnego, artykulacji różnic i rozwiązywania konfliktów; ma także swoje wyzwania i trudności. Jest to być może główny obszar, który teoria i praktyka będą eksplorować w najbliższym czasie (ze względu na wyczerpywanie się formuły demokracji przedstawicielskiej i dążenie do opracowania rzeczywiście działających mechanizmów demokracji oddolnej, uczestniczącej). Trudno przy tym oczekiwać od filozofów, by dokładnie opisali, jak ma wyglądać i co robić ruch antykapitalistyczny; to sprawa ludzi faktycznie organizujących się i podejmujących walkę. Teoretycy nie są awangardą dysponującą ezoteryczną wiedzą o tym, dokąa zmierza ruch: mogą zaledwie być jedną ze składających się na niego sił. 
1 M. Hardt, A. Negri, Commonwealth, Cambridge MA 2009, s. vii-xiv.

2 Tamże, s. 165-169.

3 Tamże, s. 169.

4 Tamże, s. 169.

5Tamże, s. viii.

6 M. Hardt, A. Negri, Multitude, London 2004, s. 204-205.

7 A. Badiou, Metapolitics, tłum. J. Barker, New YorkLondon 2006, s. 122. Stanowisko Badiou wydaje się odróżniać od stanowiska Žižka to, że mówi on o „intelektualnej dyscyplinie politycznego procesu", a nie o nadaniu ruchowi formy partii państwowej, należącej już do historii. Jednak „forma partii”, o której mówi Žižek, to również bardziej pojecie filozoficzne niż konkretna postać organizacji ruchu politycznego. Można jednak sądzić, że różnica między „zdyscyplinowanym” ruchem, będącym konsekwencją wydarzenia, a historyczną partią jest dość subtelna. Można też wnioskować, że dyscyplina intelektualna ma przełożenie na dyscyplinę praktyczną.

8 ,[B]ez formy Partii ruch pozostanie w błędnym kole »oporu« [...].” (S. Žižek, Rewolucja u bram, tłum. J. Kutyła, Kraków 2006, s. 595). W jednym z wywiadów Badiou podkreśla, że kluczową kwestią, z jaką musi się zmierzyć współczesna polityka komunistyczna, jest wykształcenie dyscypliny nowego typu, odmiennej od dyscypliny militarystycznej charakteryzującej partię państwową. Fakt, że filozof, zamiast mówić np. o organizacji, mówi o dyscyplinie, jest sam w sobie dość znamienny. Zob. A. Badiou, F. del Luchesse, J. Smith, We Need a Popular Discipline, http://www.lacan.com/baddiscipline. html (data dostępu: 28 grudnia 2011).

9 M. Hardt, A. Negri, Commonwealth, s. xiii.

10 Ch. Mouffe, Paradoks demokracji, tłum. W. Jach, M. Kamińska, A. Orzechowski, wstęp L. Koczanowicz, Wrocław 2005.

11 M. Hardt, A. Negri, Commonwealth, s. 3-22.

12 J. Locke, Drugi traktat o rządzie, [w:] tegoż, Dwa traktaty o rzadzie, tłum. Z. Rau, Warszawa 1992.

13 S. Žižek, Obiekt a jako wewnętrzna granica kapitalizmu, tłum. J. Kutyła, „Krytyka Polityczna” 2007, nr 11-12.

14 Za: C.Casarino, Time Matters: Marx, Negri, Agamben, and the Corporeal, "Strategies" 2003, Vol. 16, No. 2, s. 186-187; A. Illuminati, Recent Italian Translations of Althusser's Texts on Aleatory Materialism, http://www. borderlands.net.au/vo14no2_2005/illuminati_trans1.htm (data dostępu: 1 maja 2010).

15 A. Negri, The Constitution of Time, [w:] A. Negri, M. Mandarini, Time for Revolution, tłum. M. Mandarini, New York-London 2003, s. 31; C. Casarino, Time Matters..., s. 185.

16 Co nie znaczy, że Machiavelli w ogóle nie wartościuje - wręcz przeciwnie. Jednakże transcendentna perspektywa etyczna, odwołująca się do kryteriów zewnętrznych wobec politycznego pola sił, zostaje u niego zastąpiona immanentnym odniesieniem do specyficznie politycznej cnoty zdolnej do przeciwstawienia się Fortunie (w polskim przekładzie: losowi lub szczęściu) i podporządkowania jej sobie (zob. N. Machiavelli, Książę, tłum. Cz. Nanke, Warszawa 1984, s. 109-115; A. Negri, Insurgencies: Consituent Power and the Modern State, thum. M. Boscagli, Minneapolis 1999, s. 58).

17 Zob. N. Machiavelli, Rozważania nad pierwszym dziesięcioksięgiem historii Rzymu Liwiusza, thum. K. Żaboklicki, Warszawa 1984, s. 154-157.

18 A. Negri, Insurgencies..., s. 100.

19 G. Deleuze, Expressionism in Philosophy: Spinoza, tłum. M. Joughin, New York 1990; É. Balibar, Spinoza $i$ polityka, tłum. A. Staroń, Warszawa 2009; P. Macherey, The Encounter with Spinoza, [w:] Deleuze: a Critical Reader, red. P. Patton, Oxford-Malden MA 1996; tegoż, Negri's Spinoza: From Mediation to Constitution, [w:] The Philosophy of Antonio Negri. Vol. 1: Resistance in Practice, red. T.S. Murphy, A.-K. Mustapha, London 2005.

20 A. Negri, The Savage Anomaly: the Power of Spinoza's Metaphysic and Politics, thum. M. Hardt, Minneapolis-Oxford 1991, s. 43.

21 Tamże, s. 224.

22 Tamże, s. 202.

23 Tamże, s. 47.

24 To wprowadzenie pojęcia całości w tak kluczowym momencie konstruowania ontologii Negriego budzi pewne obawy, grozi bowiem powrotem esencjalizmu, wprowadzeniem do jego ontologii zamknięcia, autoreferencyjności; zob. M. Mutman, Difference, Event, Subject: Antonio Negri's Political Theory as Postmodern Metaphysics, [w:] The Philosophy of Antonio Negri. Vol. 2: Revolution in Theory, red. T.S. Murphy, A.-K. Mustapha, London 2007. 
25 A. Negri, The Savage Anomaly..., s. 91.

26 Tamże, s. 22-25; zob. B. Spinoza, Traktat o poprawie rozumu, [w:] B. Spinoza, Traktaty, tłum. I. Halpern-Myślicki, Kęty 2000.

27 G. Deleuze, Różnica i powtórzenie, tłum. B. Banasiak, K. Matuszewski, Warszawa 1997, s. 79.

28 Zarówno sam Spinoza, jak i Negri wykorzystują to twierdzenie do rozwinięcia tez tradycyjnie humanistycznych: conatus jest siłą ludzkiej kreatywności, przejawiającej się w wytworach ludzkiego ducha i uspołecznienia. Jednak ono samo nie zakłada konieczności przyjęcia wąskiej antropocentrycznej perspektywy, otwierając możliwość myślenia o wszystkich (dosłownie) bytach, ożywionych i nieożywionych, jako wyposażonych w jakiś rodzaj sprawczości.

29 B. Spinoza, Etyka, [w:] tegoż, Traktaty, s. 544-545.

30 T. Hobbes, Lewiatan, czyli materia, forma $i$ władza państwa świeckiego, tłum. Cz. Znamierowski, Warszawa 2005, s. 213-217; J.J. Rousseau, Umowa społeczna, tłum. A. Peretiatkowicz, Kęty 2007, s. 19-20.

31 Potentia będę odtąd określać jako moc, potestas zaś jako władzę.

32 M. Hardt, A. Negri, Imperium, tłum. A. Kołbaniuk, S. Ślusarski, Warszawa 2005, s. 99-100.

33 Tamże, s. 102.

34 M.Hardt, A. Negri, Commonwealth, s. 40-51.

35 B. Spinoza, Traktat teologiczno-polityczny, [w:] tegoż, Traktaty, s. 264-265.

36 A. Negri, Insurgencies...

37 A. Negri, Insurgencies..., s. 1-2, 13.

38 M.Hardt, A. Negri, Commonwealth, s. 371.

39 Lenin jest tu do pewnego stopnia wyjątkiem, należy bowiem do tradycji demokratycznego materializmu jedynie częściowo; Negriego interesują pewne elementy Leninowskiej teorii i praktyki, podkreśla zwłaszcza motywy zawłaszczenia produkcji i reprodukcji społecznej przez masy oraz bezpośredniego udziału mas w rządach, nie zaś teorię partii jako awangardy klasy robotniczej; o odbiorze Lenina przez Negriego zob. M. Hardt, Into the Factory: Negri's Lenin and the Subjective Caesura (19681973), [w:] The Philosophy of Antonio Negri. Vol. 2...

40 A. Negri, Insurgencies..., s. 325-326.

41 Tamże, s. 326-327.

42 M.Tronti, The Strategy of Refusal, http://www.geoc- ities.com/cordobakaf/tronti_refusal.html (data dostępu: 1 maja 2010).

43 Zob. K. Weeks, The Refusal of Work as Demand and Perspective, [w:] The Philosophy of Antonio Negri. Vol. 1..., s. 109.

44 A. Negri, Insurgencies..., s. 300. Ten postulat Negriego współbrzmi z propozycjami Ladislaua Dowbora, brazylijskiego ekonomisty zwracającego uwagę na niemożność utrzymania w dzisiejszych czasach podziału na to, co polityczne - domenę demokracji, i to, co gospodarcze - obszar rządzący się logiką rynkową i będący przedmiotem „naukowej” wiedzy ekonomicznej, a także na ograniczone i jednostronne pojmowanie produktywności w ramach tej ostatniej. Wprowadza on pojecie produktywności systemowej, obejmującej nie tylko przyrost produkcji dóbr (w tym wzrost PKB), ale także jakość życia ludzi, stan środowiska naturalnego (czy zasobów naturalnych) oraz wskaźniki rozwoju społecznego (pojęcie wprowadzone przez Amartyę Sena). Zwraca również uwagę na rolę korzyści zewnętrznych (infrastruktury gospodarcze, np. sieci komunikacyjne, edukacja, opieka zdrowotna) - wszystkich czynników zapewniających dobre funkcjonowanie gospodarki i ogólnie reprodukcję społeczną. Nie mogą one zostać poddane urynkowieniu, wymagają natomiast rozwiązań systemowych - demokratycznego aparatu władzy, nastawionego na całościowe podejście do tego, co społeczne, oraz zastąpienia paradygmatu konkurencji paradygmatem współpracy. Zob. L. Dowbor, Demokracja ekonomiczna: alternatywne rozwiązania w sferze zarzadzania społecznego, thum. Z.M. Kowalewski, Warszawa 2009, zwł. s. 24-25, 33-34, 84-119.

45 M. Hardt, A. Negri, Imperium, s. 74-75, 257-259, 284.

46 Tychże, Commonwealth, s. 131-133.

47 Tamże, s. 228.

48 M. Hardt, A. Negri, Imperium, s. 379-381.

49 Tychże, Commonwealth, s. ix; zob. A. Negri, Marx beyond Marx: Lessons on the "Grundrisse", thum. H. Cleaver, M. Ryan, M. Viano, New York 1991, s. 147-148.

50 M. Hardt, A. Negri, Commonwealth, s. 140.

51 D. Harvey, Neoliberalizm: historia katastrofy, thum. J.P. Listwan, Warszawa 2008, s. 213-214; M. Husson, Kapitalizm bez znieczulenia, tłum. Z.M. Kowalewski, 
Warszawa 2011, s. 85-99; C. Harman, Kapitalizm zombi: globalny kryzys i aktualność myśli Marksa, tłum. H. Jankowska, Warszawa 2011, s. 426-429.

52 M. Hardt, A. Negri, Commonwealth, s. 302.

53 Tamże, s. 351.

54 Tamże, s. 141-142.

55 Tamże, s. xii.

56 Tamże, s. 349.

57 M. Hardt, A.Negri, Multitude, s. 79-93; tychże, Commonwealth, s. 357

58 Tamże, s. 165.

59 Tamże, s. 340.

60 Tamże, s. 345.
61 Tamże, s. 356.

62 A. Negri, J. Revel, Dobro wspólne w rewolcie, tłum. K. Szadkowski, http://www.ha.art.pl/prezentacje/39-edufactory/1963-judith-revel-antonio-negri-dobro-wspolne-wrewolcie.html (data dostępu: 26 listopada 2011).

63 A. Negri, Hiszpańskie refleksje, tłum. M.N. Wróblewska, „Bez Dogmatu” 2011, nr 89, s. 6-10; Let All Indignados in All the Squares Join Together: Wall Street and the Growing Movement, http://ascannerdespairingly. wordpress.com/2011/10/02/\%E2\%80\%9Clet-all-indignados-in-all-the-squares-join-together\%E2\% $80 \% 9 \mathrm{D}$-wallstreet-and-the-growing-movement/ (data dostępu: 27 listopada 2011). 
JOANNA BEDNAREK - filozofka $\mathrm{z}$ zawodu

i powołania, pisarka z powołania. Pracę

doktorską Polityka poza forma. Ontologiczne

Dane adresowe autorki:

uwarunkowania poststrukturalistycznej filozofi

Międzywydziałowa „Pracownia Pytań Granicznych” UAM

polityki obroniła w 2011 roku. Publikowała

Collegium Maius

w „Nowej Krytyce”, „Czasie Kultury”

Ul. Fredry 10

i „Krytyce Politycznej”. Współpracuje z

60-701 Poznań

Pracownią Pytań Granicznych i z Interdyscy-

e-mail: bednarekjoanna87@gmail.com

plinarnym Centrum Badań Płci Kulturowej

i Tożsamości UAM. W latach 2006-2009

Cytowanie:

współpracowała z „Krytyką Polityczną”.

J. Bednarek, Jak możliwa jest absolutna demokracja?,

Obszar kompetencji i zainteresowań: na

„Praktyka Teoretyczna” nr 4/2011, http://www.praktykateoretyczna.pl/PT nr4 2011 Commonwealth/02. przecięciu poststrukturalizmu, feminizmu, marksizmu autonomistycznego i literatury.

Bednarek.pdf (dostęp dzień miesiąc rok)

Author: Joanna Bednarek

Title: How is an absolute democracy possible?

Summary: In the last part of the Empire trilogy, Commonwealth, Negri and Hardt ask about the possibility of the self-governance of the multitude. When answering, they argue that absolute democracy, understood as the political articulation of the multitude that does not entail its unification (construction of the people) is possible. As Negri states, this way of thinking about political articulation is rooted in the tradition of democratic materialism and constitutes the alternative to the dominant current of modern political philosophy that identifies political power with sovereignty. The multitude organizes itself politically by means of the constitutive power, identical with the ontological creativity or productivity of the multitude. To state the problem of political organization means to state the problem of class composition: political democracy is at the same time economic democracy.

Key words: Negri - Hardt - Commonwealth - absolute democracy - constituent power - governance 